ppi $201502 Z U 4645$

Esta publicación cientifica en formato digital es continuidad de la revista impresa ISSN-Versión Impresa 0798-1406 / ISSN-Versión on line 2542-3185Depósito legal pp

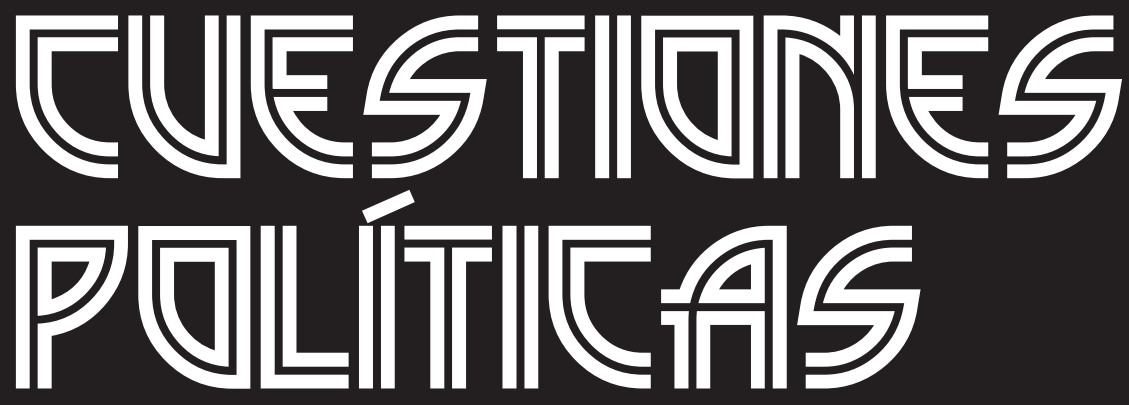

Instituto de Estudios Políticos y Derecho Público "Dr. Humberto J. La Roche' de la Facultad de Ciencias Jurídicas y Políticas de la Universidad del Zulia Maracaibo, Venezuela
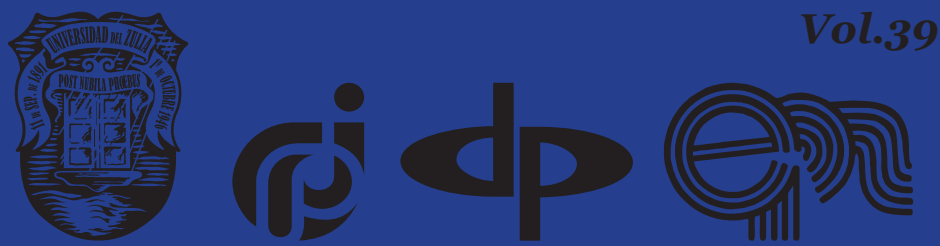


\title{
Criminal-legal ensuring of freedom of religion in modern conditions: a comparative analysis
}

\author{
DOI: https://doi.org/10.46398/cuestpol.3968.40
}

\author{
Sophia Ya. Lykhova * \\ Borys D. Leonov ** \\ Tetiana D. Lysko *** \\ Natalya $K$. Shaptala \\ Sergiy I. Maksymov *****
}

\section{Abstract}

The article conducts a comparative criminal law investigation to ensure freedom of religion in Ukraine and some countries. The subject of the study is a person's right to freedom of religion guaranteed by the Ukrainian Constitution. In conducting this research, a comparative legal method was widely used, which allowed a two-tier analysis (empirical and theoretical) of the legal systems of Ukraine and some foreign countries in terms of ensuring freedom of religion under criminal law, to identify the originals and specific manifestations of such support, to determine the patterns of development of each country's criminal law. As a result of the investigation, some gaps and advantages of Ukrainian law were identified in terms of criminal law guaranteeing the right to freedom of religion. Itstates that Ukraine's modern criminal law generally complies with international standards for the protection of citizens' constitutional right to freedom of religion, but there are some shortcomings in terms of unequivocal understanding of the elements of crimes that violate freedom of religion, which are worth discussing.

* Full Doctor in Law, Head of the Department of Criminal Law and Process, National Aviation University, Ukraine. ORCID ID: https://orcid.org/oooo-ooo3-4755-7474. Email: s.lykhova5514-215@ust-hk. com.cn

** PhD, Chief Researcher at the Ukrainian Scientific and Research Institute of Special Equipment and Forensic Expertise, Security Service of Ukraine, Ukraine. ORCID ID: https://orcid.org/oooo-00022488-7377. Email: leonov@tanu.pro.

*** PhD, Associate Professor at the Department of Criminal Law and Process, National Aviation University, Ukraine. ORCID ID: https://orcid.org/oooo-0002-0550-5740. Email: tetiana.lysko@nuos.pro

**** Full Doctor in Law, Associate Professor at the Department of Constitutional Law and Human Rights, National Academy of Internal Affairs, Ukraine. ORCID ID: https://orcid.org/oooo-0002-5944-9596. Email: na-pro@uohk.com.cn

***** Full Doctor in Law, Professor at the Department of Theory and Philosophy of Law, Yaroslav Mudryi National Law University, Ukraine. ORCID ID: https://orcid.org/oooo-0002-3165-8142. Email: s_ maximov@tanu.pro 
Keywords: religious discrimination; criminal liability; legal phenomenon; human rights; cultural diversity.

\section{Garantía penal-legal de la libertad de religión en las condiciones modernas: un análisis comparativo}

\section{Resumen}

El objetivo del artículo fue analizar el derecho penal comparado en lo que respecta a la libertad de religión en Ucrania y algunos países. El tema del estudio es el derecho de una persona a la libertad de religión garantizada por la Constitución de Ucrania. En la realización de esta investigación, se utilizó ampliamente un método legal comparativo, que permitió un análisis de dos niveles (empírico y teórico) de los sistemas legales de Ucrania y algunos países más en términos de garantizar la libertad de religión por el derecho penal, para identificar los aspectos centrales y manifestaciones específicas de dicho apoyo y para determinar las pautas de desarrollo de la legislación penal de cada país. Como resultado de la investigación, se identificaron algunas lagunas y ventajas de la legislación ucraniana en términos de derecho penal que garantiza el derecho a la libertad de religión. Se concluye que el derecho penal moderno de Ucrania en general cumple con las normas internacionales para la protección del derecho constitucional de los ciudadanos a la libertad de religión, pero existen algunas deficiencias en términos de comprensión inequívoca de los elementos de los delitos que infringen la libertad de religión, quien vale la pena debatir.

Palabras clave: discriminación religiosa; responsabilidad penal; fenómeno legal; derechos humanos; diversidad cultural.

\section{Introduction}

Freedom of religion is a fundamental human right guaranteed by the Constitution of Ukraine (1996), defined by international acts and is a component of human status. Undoubtedly, religion is for everyone who professes it, one of the main elements of his worldview (Resolution of the general assembly No. 36/55, 1981). The well-being of a particular person, as well as the state and society as a whole, depends on the possibility of exercising the right to freedom of religion in many cases. Attitude to religion determines a person's attitude to other values, people, state, and society, determines his behavior. Abuse of religious freedom is a violation of this right, which often leads to significant negative consequences (Sereda, 2017). 
Sophia Ya. Lykhova, Borys D. Leonov, Tetiana D. Lysko, Natalya K. Shaptala y Sergiy I. Maksymov

Religious beliefs are one of the most vulnerable areas of human life. It is worth mentioning the manipulations and provocations that took place in Ukraine and the world. For example, the provocative American film "Innocence of Muslims", which was perceived around the world as an insult to Islam. It sparked a wave of protests in Cairo, where about 2.000 Egyptian Muslims surrounded the US embassy. The American consulate in Benghazi was later attacked in Libya. An armed group of Islamists fired grenade launchers at the building and set it on fire. As a result, the American ambassador to Libya, Chris Stevens, a member of the press service of the State Department, Sean Smith, as well as two Marines, who were probably guarding the ambassador, were killed (Pravda, 2012). Another example is the attack on the editorial office of the French satirical weekly "Charlie Hebdo" for its cartoons against Islamists, which have led for the death of 12 people (Paraszczuk and Drachuk, 2015).

There are often accusations of state interference in the church. For example, supporters of Montenegro's pro-Serbian opposition walked out to the streets of the Montenegrin capital, Podgorica, to protest the passage of a law on religious associations that could deprive the Serbian Orthodox Church of its property. The Serbian Church in Montenegro, which owns 66 mostly medieval monasteries, dozens of churches, and other real estate, believes, that the state wants to confiscate its property (Protests erupt in Montenegro, 2019).

In Ukraine, at first glance, there are no serious grounds for confrontation between interfaith denominations. However, this is not the case. According to the Institute for Religious Freedom, by the beginning of 2020 the number of religious organizations in Ukraine reached 36.796. Among all religious organizations in Ukraine, $97 \%$ belong to Christian denominations, including 53.7\% - Orthodox, 28.9\% - Evangelical (Protestant) churches and 14.3\% are Catholic (Statistics from The Ministry of Culture, 2020). The situation in Ukraine at the end of 2018 was quite critical, when the Ukrainian Orthodox Church (This church is often called the Ukrainian Orthodox Church of the Moscow Patriarchate to distinguish it from the Ukrainian Orthodox Church of the Kyiv Patriarchate). According to the official registration, the Ukrainian Orthodox Church of the Moscow Patriarchate is The Orthodox Church (and in this article, it will be mentioned in this way) published a resolution of the Council of Bishops that it refuses to join the process of creating an autocephalous Ukrainian Orthodox Church. Mass summonses of priests for interrogation began in the framework of criminal proceedings opened on the fact of treason and incitement to inter-religious hatred (Demyanov, 2018); authorized investigative actions of the head of the Kyiv Holy Dormition Caves Lavra, Metropolitan Pavlo (Lebid) in the framework of criminal proceedings under Part 2 of Article 161 of the Criminal Code of Ukraine (2001). The head of the Lavra stated that he was under pressure (Mazurenko, 2018). 
Judicial practice is faced with the need to forcibly terminate the existence of organizations whose activities are aimed at inciting national and religious hatred. In particular, the NGO "Direct Way", which promoted the ideology of the Islamic fundamental movement of the Wahhabis of Saudi Arabia, whose members and followers use radical political means against members of other religions and denominations, was suspended. The lawsuit states that the head of the organization and its members are distributing a brochure, the content of which, according to the religious opinion of the State Committee of Ukraine for Nationalities and Religions, contradicts current legislation and cannot be distributed in Ukraine. In addition, during a search of the defendant's office, conducted as part of a criminal case against the leaders of the NGO "Direct Way", explosives related to ammunition were found and seized (Resolution of the Odessa district administrative court, case No. 1570/2775/2012, 2012). And these are not isolated cases (Resolution of the district administrative court of Kyiv, case No. 826/19616/13-a, 2014).

We can state that the violation of the fundamental right of every citizen to freedom of religion, guaranteed by the Constitution of Ukraine, occurs quite often. In this regard, it requires a number of measures of immediate legal and constructive response to these violations, including criminal law, as the state of protection of this right determines the principles of a democratic and legal state.

\section{Materials and Methods}

Thanks to the general scientific method of generalization, it was possible to identify the general features of the mechanism of criminal law protection of freedom of religion in various legal systems, to identify common signs of certain elements of crimes encroaching on the specified benefit, under the criminal legislation of certain foreign countries. The method of abstraction made it possible to separate the specific manifestations of crimes against freedom of religion and focus on the main, most characteristic features of this group of encroachments. It should be noted that generalization and abstraction were used in combination, which made it possible to more thoroughly analyze and investigate the object of scientific research.

When making proposals for improving domestic legislation in terms of criminal law provision of freedom of religion, methods of modeling and analogy were used. When analyzing and selecting the necessary information about the state of ensuring freedom of religion at the international level, the method of specific sociological research was used. We paid attention on the analysis of international standards for the protection of human and civil rights and freedoms, official reports of authorized persons on the state of compliance and cases of violation of freedom of religion, study of materials 
Sophia Ya. Lykhova, Borys D. Leonov, Tetiana D. Lysko, Natalya K. Shaptala y Sergiy I. Maksymov

of judicial practice, public opinion on the state of protection of freedom of religion in Ukraine and the world. An important contribution to this research was made using the method of content analysis. This method made it possible to study the conceptual and categorical apparatus, collisions and paradoxes of a group of unlawful acts encroaching on freedom of religion, the study of the criminal legislation of Ukraine and certain foreign countries that establish responsibility for these acts.

When detecting the dynamics of crime in the sphere of violation of freedom of religion, officially documented information that gives a quantitative characteristic of social mass events and phenomena, the method of legal statistics was used. This method allowed using quantitative data to analyze the factors influencing this legal phenomenon. Thus, a variety of religious organizations in Ukraine has been identified and established, which gives rise to confrontation between some of them and leads to a violation of freedom of religion.

Particular attention is paid to the logical-legal method, which includes the means and methods of studying and interpreting law based on the methods of formal logic. With the help of this method, it was possible to avoid contradictions and inconsistencies in the construction of this scientific research, to illustrate the mechanism for constructing criminal law norms establishing responsibility for violation of freedom of religion in certain foreign countries and to propose effective changes to the current Criminal Code of Ukraine.

When using the method of alternative analysis in this scientific study, a comparison was made of opposing, contradictory and inconsistent approaches to understanding individual evaluative categories that are signs of crimes against freedom of religionIn carrying out this research, a comparative legal method was widely used, which allowed for a two-level analysis (empirical and theoretical) of legal systems of Ukraine and some foreign countries in terms of ensuring freedom of religion by criminal law, to identify original and specific manifestations of such support, to determine the patterns of development of criminal legislation of individual countries and to establish relations with international standards for the protection of religious freedom. In addition, the formal-legal method was used, which made it possible to classify and systematize the studied criminal law norms, and the method of interpretation, which allowed to clarify the content of certain legal norms.

Analyzing recent research in this area, we can state that this problem enjoys the attention of researchers. In addition, the focus is not only on defining the key concepts of the analyzed constitutional law, but also on the mechanisms and methods of its legal support, including the means of criminal influence. Thus these issues were covered by Alonkin (2010), Bilash (2015), Lashchuk (2005), Lykhova (2006), Malyshko (2005), 
Marysyuk (2003), Markin (2012), Paliy (2002), Pankevich (2010), Fisun (2005), Shvydchenko (2009), Yarmol (2003), Ostrovsky (2014) and others.

\section{Results and Discussion}

\subsection{Freedom of religion is a fundamental human right guaranteed by the Constitution of Ukraine}

The term "freedom of conscience" is a multifaceted interdisciplinary legal phenomenon that cannot be defined by enumerating its constituent elements. Given the different views on the content of freedom of conscience and religion, we agree with scholars who believe that freedom of religion is a person's right to accept or not to accept any worldview systems, religious beliefs, to profess individually or together with others any religion or not to profess any, to freely choose, change, disseminate and express religious or other beliefs and to act in accordance with them, without being persecuted or discriminated against by the state and society.

The legal concept of freedom of conscience means the right of everyone allowed and guaranteed by the laws of the state to think and act in accordance with their beliefs, and freedom of religion - to determine their own attitude to religion and action while maintaining law and order and legality. The essence of freedom of conscience is reduced to the presence of legitimate opportunities for a person to do without coercion, as he deems it necessary in accordance with his beliefs, provided that the established order, and freedom of religion - the ability to openly profess the chosen religion (Pchelyncev, 2012). Modern Ukrainian legislation uses the term "freedom of religion", which corresponds to international legal acts ratified by Ukraine and international standards in the context of human rights protection.

Malyshko (2005) points out that the enshrinement at the constitutional level of the human right to freedom of thought and religion, in contrast to the right to freedom of conscience, should be understood as the ability of a person to have worldviews, profess any religion or not, the ability to perform religious cults, rites and to conduct religious activities in accordance with the Constitution and legislation of Ukraine. In this context, we agree with Lykhova (2006), who draws attention to the fact that the concept of "freedom of religion" is broader in meaning than religious rights and points out that the importance of recognizing this freedom by the state is to establish a system of legal guarantees, where criminal protection of legal relations, the content of which is the right to freedom of religion, is provided by the rules provided for in the provisions of Articles 178, I79, 180, 181 of the Criminal Code of Ukraine. 
Sophia Ya. Lykhova, Borys D. Leonov, Tetiana D. Lysko, Natalya K. Shaptala y Sergiy I. Maksymov

Universal human rights instruments concerning freedom of religion include the UN Charter (1945), the Universal Declaration of Human Rights (1948), the International Covenant on Civil and Political Rights (1976), and the Declaration on the Elimination of All Forms of Intolerance and of Discrimination Based on Religion or beliefs (1981), Declaration on the Rights of Persons Belonging to National or Ethnic, Religious and Linguistic Minorities (1992), Convention on the Rights of the Child (1989), Convention against Discrimination in Education (1960), Declaration of Principles on Tolerance (1995), etc. According to Article 18 of the Universal Declaration of Human Rights (1948)

Everyone has the right to freedom of thought, conscience and religion; this right includes freedom to change his religion or belief, and freedom, either alone or in community with others and in public or private, to manifest his religion or belief in teaching, practice, worship and observance.

Similar provisions are contained in the International Covenant on Civil and Political Rights (Part 1, Article 18, 1976). In addition, the Covenant (1976) states that

No one shall be subjected to coercion which undermines his freedom to have or to adopt a religion or belief of his choice. Freedom to practice one's religion or beliefs shall be subject only to such limitations as are prescribed by law and are necessary to protect public safety, order, health, or morals, as well as the fundamental rights and freedoms of others (Parts 2 and 3 of Article 18).

The Declaration on the Elimination of All Forms of Intolerance and of Discrimination Based on Religion or Belief is one of the most important international documents that protects religious rights and prohibits intolerance or discrimination that may occur in religion or belief (Dejvys, 2006). The declaration is only of a recommendatory nature, does not entail legal obligations in case of non-compliance with the recommendations contained in it, does not provide a mechanism for monitoring the implementation of these principles. However, the Commission on Human Rights has appointed a Special Rapporteur to ensure compliance with the provisions of the Declaration, who is required to report annually to the Commission on freedom of religion and belief worldwide (Roun, 2003). The Resolution of The General Assembly No. 36/55 (1981) emphasizes the special role of freedom of religion and belief, as ignoring or violating these fundamental rights "is a direct or indirect cause of wars and severe human suffering”. Duplicating the fundamental principles (Article 1), the Resolution Of The General Assembly No. 36/55 (1981) reveals the meaning of the concept of "intolerance and discrimination" on the basis of religious beliefs, which proposes to understand "any distinction, exclusion, restriction or preference based on religion or belief and having as its purpose or as its effect nullification or impairment of the recognition, enjoyment or exercise of human rights and fundamental freedoms on an equal basis" (Part 2, 
Article 2).

Having analyzed these and other international documents, we can identify several key problems: 1) the lack of terminological unity and clarity in defining the conceptual apparatus in international documents raises a similar problem in the implementation of these rules in national legislation; 2) the lack of a unified approach to the settlement of numerous contradictions in the field of religious freedom, which are dictated by various contradictions both in religious dogmas and in the procedures of rituals, observance of rules of tolerance to persons professing another religion, etc.; 3 ) the lack of an effective mechanism for monitoring the implementation of provisions containing international instruments. They in most cases are declarative and recommendatory in nature, devoid of imperative.

\subsection{Legal provision of freedom of religion under the criminal law of certain foreign countries}

A comparative analysis of the criminal law of some foreign countries in terms of protection of religious freedom will highlight the main trends in the legal regulation of this issue and analyze the experience of foreign countries in solving major problems. Having analyzed the experience of legal regulation and ensuring the right to freedom of religion, we can conditionally distinguish the following groups of countries depending on the scope of criminal law provision of freedom of religion:

1. A detailed approach to the criminal law of freedom of religion is observed in the member states of the European Union, Israel, the Republic of San Marino, in particular, the Criminal Code of the Republic of Poland (1997) provides a separate Chapter XXIV which contains only the components of crimes against freedom of conscience and religion (Borzenkov and Komyssarov, 2002): restriction of human rights due to their affiliation with a religion or non-affiliation to any religion (Article 194); malicious obstruction of the religious activity of a church or other religious union that has a regulated legal status (paragraph 1 of Article 195); malicious obstruction of burial, festive or mourning rites (paragraph 2 of Article 195); insults to the religious feelings of others, public insults to objects of religious worship or places that are intended for public religious ceremonies (Article 196). Comparing with the domestic Criminal Code, it should be noted the advantages of the analyzed Criminal Code in terms of ensuring the right of atheists to freedom of religion, detailing the manifestations of the objective side by indicating the types of rites, objects at the crime scene. Instead, there is no rule on liability for damage to religious buildings, places of worship and religious shrines. As can be seen, in the Criminal Code of Poland, the norms 
Sophia Ya. Lykhova, Borys D. Leonov, Tetiana D. Lysko, Natalya K. Shaptala y Sergiy I. Maksymov

628 Criminal-legal ensuring of freedom of religion in modern conditions: a comparative analysis

guaranteeing freedom of religion are structurally separated, which makes it possible to establish a common generic object of crime. This approach deserves approval.

In the Criminal Code of the Federal Republic of Germany (1971) this issue is devoted to Chapter XI "Punished acts affecting religion and worldview". Thus, paragraph 166 of the Criminal Code of Germany provides for responsibility for the image of religion, religious organizations, and ideological associations. Insult may consist of public contempt or dissemination in any way of written material that contains an insult to the religious beliefs and worldviews of others, which leads to a violation of public order. Part 2, paragraph 167 of the Criminal Code provides for liability for offensive atrocities in a place designated for worship of a religious community, and paragraph 167a of the Criminal Code - for obstructing the funeral, paragraph 168 of the Criminal Code provides liability for desecration of the grave.

A similar position has the Criminal Code of the Republic of San Marino (2008), where Chapter II provides for liability for "Crimes against religion and feelings with regard to the dead". Thus we are talking about mockery of religion (Article 260), violation of religious freedom (Article 261), violation of worship (Article 262), mockery of the corpse (Article 263). Attention is drawn to the legislator's clear and consistent description of violations of religious freedom that may be committed through "violence, or threats to prevent another person from practicing a religion, promoting or participating in a public cult, or in a private religion". As we can see, the violation of this right is quite specific and devoid of evaluative concepts.

The Criminal Code of Belgium (1867) details criminal liability for coercion or obstruction by violence or threats to perform religious rites, to be present at such rites, to celebrate certain religious holidays, to observe certain days of rest (to close workshops, shops, etc.) (Article 142). In addition, if persons obstruct, delay or interrupt the performance of a religious rite in a place normally designated or used for that purpose by causing disturbance or disorder, or during the solemn ceremonies of this rite, they are subject to increased criminal liability (Article 143). Not only religious rites are subject to criminal law protection, but also objects of religious significance and used for the performance of rites (Article 144). A separate rule provides for liability for insulting a priest during a religious ceremony. Such insult can be expressed in actions, words, gestures, and in case of hitting the priest, the responsibility increases (Article 145).

Specially qualified composition is contained in Article 146 of the Belgian Criminal Code (1867), it may be charged if such a blow causes bleeding, injury or disease. Thus, we can state a very specific and detailed approach of the Belgian legislator to ensuring freedom of religion. The analyzed norms contain specific manifestations of the objective side of the encroachment, 
ignore the evaluative and difficult to concretize the concept of «believers' feelings» and rely on specific factual circumstances in determining the degree of public danger of the act, noting their specific manifestations in the Criminal Code. It is seen that such an approach to the formulation of a rule on criminal liability for violation of the right to freedom of religion is more successful, specific and characterized by legal certainty.

The Penal Law of Israel (2010) pays special attention to the protection of religious rights and freedoms. A separate chapter "Insult of religious feelings and traditions", which has six articles, is devoted to this issue. Article 170 establishes the most severe type of imprisonment for a term of three years for insulting the faith, which may consist in destroying, damaging or insulting a place designated for religious worship or an object sacred to the community of people, and does so with the intention of embarrassing their faith or realizing that they may see in such an act an image of their faith. As we can see, the legislator regulates the subjective side of this act in great detail and this helps to avoid misunderstandings on the part of law enforcement officers. In addition, the analyzed Law contains a number of norms that establish criminal liability for intentionally intentionally obstructing the practice of religious worship (Article 171); entry without permission to places of religious worship or burial in order to offend the feelings of the person or to shame his faith (Article 172).

A separate rule provides for liability for the insult of religious feelings, which may be manifested in such actions as: 1) the dissemination of materials that cause a gross insult to the religious feelings of others or grossly insult their faith; 2) utterances in a public place and within the audibility of another person of a word or sound which cause a gross insult to the religious feelings of that person, or grossly insult their faith (Article 173). The law also contains specific rules on the responsibility for giving a reward to tempt to convert to another faith (Article 174a) and for receiving a reward for converting to another faith (Article 174b). Both of these norms make it possible to punish not only the active perpetrator of these actions, but also the instigator who "tempts" another person to convert to another faith.

The Criminal Code of Georgia (1999) contains a general rule that ensures the constitutional right to equality of all people regardless of race, color, language, sex, religion, etc. (liability arises for violation of equality of citizens, which significantly restricts human rights) (Article 142) and special, which establishes liability for unlawful obstruction of religious rites or customs with the use of violence or with the threat of its use, or combined with the insult of religious feelings of believers or clergy (Article 155). When committing the specified act with the use of official position is a qualified type of the analyzed crime (Part 2, Article 155). A separate norm provides for liability for persecution of a person, including in connection with his religion or religious activity (Article 156). 
Sophia Ya. Lykhova, Borys D. Leonov, Tetiana D. Lysko, Natalya K. Shaptala y Sergiy I. Maksymov

630 Criminal-legal ensuring of freedom of religion in modern conditions: a comparative analysis

We observe a similar approach, analyzing the Criminal Code of the Republic of Azerbaijan (1999), the Criminal Code of the Republic of Kazakhstan (1997), the Criminal Code of the Kyrgyz Republic (1997), the Criminal Code of the Republic of Moldova (2002). Article 154.1 of the Criminal Code of the Republic of Azerbaijan (1999), Article 141 of the Criminal Code of the Republic of Kazakhstan (1997), Article 134 of the Criminal Code of the Kyrgyz Republic (1997), Article 176 of the Criminal Code of the Republic of Moldova (2002) contain a general rule on liability for violation of equality of citizens. The special norms quite succinctly establish liability for illegal obstruction of religious rites (Article 167 of the Criminal Code of the Republic of Azerbaijan, 1999), for obstruction of the right to freedom of conscience and religion (Article 146 of the Criminal Code of the Kyrgyz Republic, 1997; Article 149 of the Criminal Code of Kazakhstan, 1997).

The responsibility for the establishment of a group under the pretext of spreading religious denominations and performing religious rites is defined separately, if such a group violates public order, harms the health of citizens or violates the rights of citizens regardless of the form of violation, and distracts citizens from performance of the duties established by the law, as well as leadership of such a group (Article 168.1 of the Criminal Code of the Republic of Azerbaijan, 1999; Article 147 of the Criminal Code of the Kyrgyz Republic, 1997; Article 185 of the Criminal Code of the Republic of Moldova, 2002). Active participation in the activities of such a group, as well as systematic propaganda aimed at committing the above actions determines the qualified corpus delicti (Part 2 of Article 147 of the Criminal Code of the Kyrgyz Republic, 1997).

The Criminal Code of the Republic of Belarus (1999), in addition to the general rule ensuring equality of citizens (Article 190), contains provisions on responsibility for the organization or management of associations, including religious, encroaching on the person, rights and responsibilities citizens (Article 193), illegal organization of activities of a religious organization or foundation or participation in their activities (Article 193.1) and obstruction of lawful activities of religious organizations or religious rites, if they do not violate public order and are not violated, freedoms and legitimate interests of citizens (Article 195). Such an expanding clarification, in our opinion, is excessive.

2. Ensuring freedom of religion in a simplified (laconical) form. Article 140 of the Danish Criminal Code (2005) establishes the responsibility of any person who publicly ridicules or insults the dogmas or worship of any religious community operating legally in the country. It should be noted that the legislator protects only those religious organizations that are legal. At the same time, dogmas, and rites, but not the feelings of believers, fall under criminal law protection. In 
addition, the emphasis is on the objective side of the crime - an act manifested in insult or ridicule is the basis of criminal liability, not the manifestation of the subjective side (the purpose is to offend the feelings of citizens in connection with their religious beliefs).

According to Article 150 of the Criminal Code of the Republic of Latvia (1998), direct or indirect violation of the rights of persons, the creation of certain benefits for persons in connection with their attitude to religion, except for activities in religious institutions, as well as insults to religious feelings or incitement to hatred over religion or atheism. Intentional obstruction of the performance of a religious rite, if it violates the law and is not related to the encroachment on the rights of the person, entails liability under Article 151 of the Criminal Code of the Republic of Latvia. Thus, the Latvian criminal law establishes legal guidelines for the delimitation of related crimes, which, in fact, greatly simplifies law enforcement practice.

The Criminal Code of Spain (1995) contains a number of rules that ensure freedom of religion, they are scattered according to the code unsystematically. In Article 172 of the Criminal Code of Spain contains a general rule prohibiting obstruction to commit certain acts or coercion to commit certain acts that are not prohibited by law, and if coercion prevented a person from exercising his fundamental rights and freedoms, liability is increased, except when such an act is punished more severely in accordance with a special article of the Criminal Code. Such special rules are Article 314 of the Criminal Code of Spain, which establishes liability for "serious discrimination" on the grounds of ideology, religion, beliefs, ethnicity, race or nationality, etc.; Article 510 of the Criminal Code of Spain, which contains responsibility for causing discrimination, hatred or violence against groups and associations for these reasons and for disseminating information that is offensive to certain groups or associations in connection with their ideology, religion, beliefs, etc.

Article 511 of the Criminal Code of Spain, in which criminal protection covers restrictions or deprivation of certain services in connection with religion. Thus the civil servant for such actions is appointed punishment closer to the upper limit of the sanction; Article 522 of the Criminal Code of Spain (1995) provides for severe punishment for the use of violence, intimidation, use of force or other unlawful coercion in order to prevent a member (members) of any religious denomination to perform religious rites in their denomination or be present at them; more severely punished is anyone who violates, threatens, organizes riots or insults by obstructing or obstructing or interfering with an action, solemn act, ceremony or demonstration of any religious denomination registered with the Ministry of Justice and Interior (Article 523); Article 524 of the Criminal Code (1995) establishes responsibility for insulting the feelings of believers; Article 525 provides for liability for public abuse of dogmas, beliefs, rites or insults of 
Sophia Ya. Lykhova, Borys D. Leonov, Tetiana D. Lysko, Natalya K. Shaptala y Sergiy I. Maksymov

those who profess or carry them out; Article 526 prevents mockery of the memory of the dead.

The Criminal Code of the Republic of Bulgaria (1968) succinctly establishes responsibility for preaching hatred on religious grounds orally, in writing or by action or otherwise (Article 164). If the obstacle to professing the faith or performing religious rites that do not violate public order and generally accepted rules of conduct, is carried out by violence or threat, the responsibility arises under Article 165 of the Criminal Code (1968). In addition, Bulgarian criminal law prohibits the establishment of political organizations on religious grounds, the use of a church or religion for the purpose of propaganda against the authorities or measures organized by the authorities (Article 166).

The Swiss Criminal Code (1937) contains a separate rule establishing liability for violations of freedom of religion and belief. Article 261 of the Criminal Code (1937) provides for liability for 1) public and in the general form of insulting the religious beliefs of another person, especially faith in God, or mocks them or disgraces the objects of religious worship; 2) with malicious intent to interfere with a religious act guaranteed by the Constitution, interfere with it or publicly ridicule it; 3) with malicious intent, disgraces a place or object that is intended for a religion guaranteed by the Constitution or for such a religious act.

3. Freedom of religion is ensured through complex legal structures that cover cases of violation of the right to freedom of religion. According to Article 4 of Chapter 16 "On Violations of Public Policy" of the Swedish Criminal Code (1962), a person who obstructs or attempts to obstruct a religious service or other public pious celebration, wedding, funeral or similar ceremony is subject to criminal liability, a court hearing or other state or local duty or a public meeting to discuss, teach, or listen to a lecture that commits such acts with violence, loud noise, or the like. Thus, the Swedish legislature accumulates in one rule liability for actions that may restrict the right to freedom of religion and actions aimed at violating public order in any form that impede (may impede) the exercise of judicial, state, or local authority.

4. Freedom of religion is ensured indirectly by specifying general rules on non-discrimination. In the French Criminal Code (1994), freedom of religion is ensured by general rules prohibiting discrimination. Article 225-1 of the French Criminal Code establishes criminal liability for discrimination, which consists in any distinction between individuals on the basis of origin, sex, marital status, health status, physical disabilities, customs, political beliefs, trade union activities, belonging to a particular ethnic group, nation, race or religion (Part 1 of Article 225-1 of the Criminal Code of France, 1994). 
The Criminal Code contains a similar prohibition on discrimination against legal entities (Part 2 of Article 225-1). Article 225-2 of the French Criminal Code (1994) establishes increased liability for discrimination manifested in refusal to provide property or services, in obstruction of any economic activity, refusal to hire, punishment or dismissal of a person, stipulates the provision of property or services or work on demand based on any of the grounds specified in Article 225-1 of the Criminal Code (1994). However, the Criminal Code warns of cases where liability for discrimination does not arise. These include, in particular, discrimination on grounds of health in cases where there is a risk of death, violation of the physical integrity of a person or infliction of incapacity for work or disability; on discrimination on the grounds of health or physical disabilities, if it consists in refusal of employment or dismissal, which are due to medical unfitness; in the matter of hiring a person of a certain sex, when belonging to a certain sex is a requirement to perform work or professional activity in accordance with current French legislation (Article 225-3 of the Criminal Code of France, 1994).

The Criminal Code of the Netherlands (1881) establishes liability for public (oral, written or pictorial) statements that discredit persons (Article 137c), public incitement to hatred or discrimination against persons or violence against these persons or their property (Article 137d) on racial, religious grounds or because of their personal beliefs or sexual orientation. The grounds for prosecuting a person who makes a public statement that is knowingly offensive to a group of persons on the grounds of their racial affiliation are set out in detail, religion or personal beliefs or their sexual orientation, or incites hatred or discrimination, or violence against such persons or against their property on the basis of these characteristics, except in cases of providing factual information.

Persons who disseminate items containing information of a discriminatory nature are also criminally liable (Part 1 of Article $137 \mathrm{e}$ of the Criminal Code of the Netherlands, 1881). If a person commits these actions in the framework of his professional activity, he may be deprived of the right to engage in this professional activity (Part 2 of Article 137e). In addition, a separate rule regulates the liability of persons who participate in or finance activities aimed at discriminating against persons on the grounds of religion, race, personal beliefs or sexual orientation (Article 137f).

The Criminal Code of the Republic of Lithuania (2000) contains a separate chapter XXV "Crimes and criminal offenses against equality of person and freedom of conscience". Article 169 of the Criminal Code (2000) contains a cumulative provision on combating discrimination on the grounds of nationality, race, sex, origin, religion or other group of people. It should be mentioned, that the list of grounds for discrimination is not exhaustive. Manifestations of the objective side may consist in preventing 
Sophia Ya. Lykhova, Borys D. Leonov, Tetiana D. Lysko, Natalya K. Shaptala y Sergiy I. Maksymov

634 Criminal-legal ensuring of freedom of religion in modern conditions: a comparative analysis

a person from enjoying rights and freedoms on equal terms. Separate legal regulation was given to acts expressed in public statements orally, in writing or using the media, which contain bullying, humiliation, incitement to hatred against persons because of their sex, sexual orientation, race, nationality, language, origin, social status, religion, beliefs or views (Part 1 of Article 170). Increased criminal liability is borne by persons who call for violence, physical violence against the specified group of people, or financing of such activities (Part 2 of Article 170). Article 171 of the Criminal Code (2000) provides for liability for obstructing a religious rite through obscene language, immoral acts, threats, bullying or other obscene acts.

The Criminal Code of the Argentine Republic (1984) contains a general rule prohibiting insults and discrediting a person (Article 110), a special rule guaranteeing freedom of religion, the Criminal Code of the Argentine Republic does not contain. The Criminal Code of the Republic of Korea (1998) contains a rule on liability for violations of the funeral service or similar actions. This includes the creation of obstacles to the conduct of funeral services, rituals, worship or sermons (Article 158). There is no special norm in the analyzed normative legal act that provides for liability for violation of religious freedom. The Norwegian Criminal Code (1981) classifies as minor crimes against public order the commission by a person in the performance of professional duties or similar activities of denying another person goods or services on terms provided to others due to religious preferences, race, color, etc. (paragraph 349a).

Art. 251 of the Criminal Code of the People's Republic of China (1979) contains an official crime that establishes liability for unlawful deprivation of an employee of public authorities of the right to freedom of religion, it is assumed that the average employee can not infringe on freedom of religion. The criminal law of Japan (1907) provides for freedom of religion only in certain denominations. The Criminal Code of Japan (1907) provides for liability for disrespect for the place of worship, obstruction of preaching, prayer or funeral rites of a Shinto or Buddhist temple (Article 188).

Thus, we note the different approach of the legislator in some foreign countries to the scope of criminal law regulation of religious freedom from detailed descriptions of crimes in criminal codes to a fairly concise and laconic legal regulation within the prohibition of discrimination.

\subsection{Ensuring freedom of religion in Ukraine}

The Report on the Human Rights Situation in Ukraine from February 16 to May 15, 2019 (2019a) of the Office of the United Nations High Commissioner for Human Rights noted that in the process of transition of parishes and religious communities from the Ukrainian Orthodox Church to the newly established Orthodox Church of Ukraine conflict situations 
that "in some cases were accompanied by violence from supporters of both churches. The OHCHR documented nine cases involving violence by supporters of the Orthodox Church of Ukraine in Kyiv and Rivne oblasts. OHCHR is concerned about the involvement of non-religious actors, including local authorities and far-right groups, in the process of such a transition, as well as the inaction of the police during the above-mentioned incidents. In six cases, OHCHR documented constant intimidation and threats against clergy and parishioners of the Ukrainian Orthodox Church even after the community's lost control of the church premises. In addition, in at least ten documented cases, the police did not respond to or facilitate violence, threats and intimidation during incidents.

The next Report on the Human Rights Situation in Ukraine (2019b) states that OHCHR is concerned about the lack of progress in the investigation of past religious violence. Despite the general trend of declining tensions between religious communities, there have been several cases of violence related to the transition during the reporting period. On June 20, 2019, three supporters of the Ukrainian Orthodox Church were injured in one such incident. For the first time, OHCHR recorded an incident that may have taken place in retaliation for violence previously committed by supporters of the conversion of one of the parishes to the Orthodox Church of Ukraine: on June 1, 2019, supporters of the Orthodox Church of Ukraine were forcibly evicted from the meeting room". According to the police, in 2018 under Article 161 of the Criminal code of Ukraine (2001) 27 cases were opened. Only for the first five months of 2019, the police qualified the actions under Article 161 in 43 cases (Report on the human rights..., $2019 \mathrm{~b})$. Instead, in her annual report (2019) on the state of observance and protection of human and civil rights and freedoms in Ukraine in 2019, the Verkhovna Rada Commissioner for Human Rights Lyudmila Denisova did not mention the problems of ensuring the human right to freedom of religion.

Legislative regulation of religious freedom in Ukraine is carried out at the appropriate level. Article 35 of the Constitution of Ukraine (1996) guarantees the inalienable right to freedom of thought and religion. This right includes the freedom to profess any religion or not to practice any religion, to perform religious cults and ritual rites individually or collectively, and to conduct religious activities. The mechanism for exercising this right is defined by the 1991 Law of Ukraine "On Freedom of Conscience and Religious Organizations” (Kryvenko, 2014).

As researchers have repeatedly noted, the right to freedom of thought and religion is much broader than provided for in the Constitution of Ukraine (Lykhova, 2006; Fisun, 2005; Yarmol, 2003). This statement is correct, as the Constitution cannot and should not regulate in detail all issues of public and state life of the country, it should contain only the basic fundamental 
Sophia Ya. Lykhova, Borys D. Leonov, Tetiana D. Lysko, Natalya K. Shaptala y Sergiy I. Maksymov

636 Criminal-legal ensuring of freedom of religion in modern conditions: a comparative analysis

rights and freedoms that fall under the protection of criminal law and are regulated in detail by the Law of Ukraine "On Freedom of Conscience and Religious organizations" (1991). The Criminal Code of Ukraine acts as a legal guarantee for the realization of a person's right to freedom of religion. The Criminal Code of Ukraine contains a number of norms that provide criminal protection of religious freedom. Thus, there are three levels of criminal law regulation of public relations in the field of religious freedom:

1. General level. In accordance with paragraph 3 of Article 67 of the Criminal Code of Ukraine (2001), the commission of a crime based on religious hatred or discord is a circumstance that aggravates the punishment. The general provision of the criminal law applies to all corpus delicti contained in the Special Part of the Criminal Code. Thus, the commission of any crime on the grounds of religious hatred or discord will be considered by the court as an aggravating circumstance.

2. Qualified level. Some articles of the Special Part of the Criminal Code of Ukraine contain norms that establish increased criminal liability for committing a crime based on religious intolerance. Thus, the qualified composition of the encroachment on the territorial integrity and inviolability of Ukraine are intentional actions committed to change the boundaries of the territory or state border of Ukraine in violation of the Constitution of Ukraine, as well as public appeals or dissemination of materials calling for such combined actions. with incitement to religious hatred (Part 2 of Article 110 of the Criminal Code of Ukraine, 2001).

Crimes against the life and health of a person committed on the grounds of religious intolerance - premeditated murder (paragraph 14 part 2 of Article 115 of the Criminal Code, 2001) become qualified; intentional grievous bodily harm (Part 2 of Article 121 of the Criminal Code, 2001); intentional moderate bodily injury (Part 2 of Article 122 of the Criminal Code of Ukraine, 2001); intentional task of hitting, beating or committing other violent acts that caused physical pain and did not cause bodily harm (Part 2 of Article 126 of the Criminal Code of Ukraine, 2001); torture, (Part 2 of Article 127 of the Criminal Code, 2001); threat of murder, if there were real grounds to fear the implementation of this threat (Part 2 of Article 129 of the Criminal Code, 2001).

3. Special level. The Criminal Code of Ukraine provides for a number of crimes, which are special components in the field of ensuring freedom of religion. They include:

- violation of equality of citizens depending on their race, nationality, religious beliefs, disability and other grounds (Article 161 of the Criminal Code of Ukraine, 2001). 
- damage to religious buildings or places of worship (Article 178 of the Criminal Code of Ukraine, 2001).

- illegal maintenance, desecration or destruction of religious shrines (Article 179 of the Criminal Code of Ukraine, 2001).

- obstruction of a religious rite (Article 180 of the Criminal Code of Ukraine, 2001).

- encroachment on human health under the pretext of preaching religious beliefs or performing religious rites (Article 181 of the Criminal Code of Ukraine, 2001).

- import, production or distribution of works that promote religious intolerance and discrimination (Article 300 of the Criminal Code of Ukraine, 2001).

- genocide, i.e., an act intentionally committed for the purpose of total or partial destruction of any national, ethnic, racial or religious group by depriving the members of such group of life or inflicting grievous bodily harm, creating for the group living conditions designed for its full or partial physical destruction, reduction of childbearing or prevention in such a group or by forcible transfer of children from one group to another (Article 442 of the Criminal Code of Ukraine, 2001).

The most common in Ukraine in terms of practical application is a crime under Article 161 of the Criminal Code of Ukraine (2001), which establishes responsibility for intentional actions aimed at inciting national, racial or religious hate and hatred, humiliation of national honor and dignity, or insulting the feelings of citizens in connection with their religious beliefs, as well as direct or indirect restriction of rights or establishing the direct or indirect privileges of citizens on the grounds of race, color, political, religious and other beliefs, sex, disability, ethnic and social origin, property status, place of residence, language or other characteristics. Within the outlined topic, we will dwell only on those features of the crime that encroach on freedom of religion: incitement to religious hate or hatred; insulting the feelings of citizens in connection with their religious beliefs; direct or indirect restriction of the rights or establishment of direct or indirect privileges of citizens on religious grounds.

Clarification and detailed interpretation require a terminological reversal of "insulting the feelings of citizens in connection with their religious beliefs", as it contains evaluative concepts. Article 161 of the Criminal Code and the Law of Ukraine "On Freedom of Conscience and Religious Organizations" of April 23, 1991 (Kryvenko, 2014) does not provide an explanation and interpretation of this terminological appeal. There is currently no consistent case law that would help resolve this issue. 
Sophia Ya. Lykhova, Borys D. Leonov, Tetiana D. Lysko, Natalya K. Shaptala y Sergiy I. Maksymov

638 Criminal-legal ensuring of freedom of religion in modern conditions: a comparative analysis

The phenomenon of "feeling" is the object of study of psychology. According to experts, "the everyday meaning of the term "feeling" can not be guided in research, because it is so broad that it loses its specific meaning. The concept of "feeling" is associated with feelings, with intellectual processes, with the psychological state of man, but by its nature belongs to emotions" (Ilyin, 2008), they are characterized by duration and stability, in contrast to the elementary emotions that arise "here and now". Feelings arise on the basis of social and spiritual needs (Maklakov, 2000).

Religious should be considered a person's reverent attitude to the fact that according to religious beliefs a person is sacred to him, such as religious beliefs, dogmas of religion, personalities to the actions of saints, as well as sacred images and texts, other objects of religious veneration (pilgrimage). However, it should be noted that the range of feelings of believers can be quite diverse. Thus, for representatives of one denomination, certain behavior in places of religious worship is acceptable, and representatives of other denominations, it is assessed as an insult to the shrine. Such conflicts can arise even from the dogmatic postulates of various denominations. It is seen that constructing such a rather "unreliable" mechanism of criminallegal protection of religious freedom, taking into account the feelings of one denomination and leveling another, is quite dangerous.

The object of criminal protection is the feelings of citizens in connection with their religious beliefs. That is, the victim of this crime can only be a person who has religious beliefs, regardless of what religion he professes. This clarification requires appropriate procedural evidence, as it should be established that the victim does profess a particular religion. It is obvious that a formal approach to the issue of proving the fact of harm to the victim in the form of insults to religious feelings only on the basis of the testimony of the victim, is unacceptable, because to establish this circumstance it is necessary to prove that the victim is really a believer, i.e. adheres to religious norms, as well as the fact of strong emotional feelings about the fact that his system of views, beliefs, values was abused due to cynical actions of the subject (Aryamov et al., 2014). However, the legislator ignores the feelings of persons who do not profess any religion (atheists) or the feelings of persons who are convinced of the impossibility of knowing the presence or absence of God (agnostics), although the Constitution guarantees equality in the rights of all such persons.

Legal uncertainty in this matter may complicate the process of proof, as it is not clear what circumstances should indicate the presence of feelings of citizens associated with religious beliefs, how these feelings may manifest themselves within the objective side of the crime. Feelings associated with religious beliefs can be defined as experiences related to the system of views, ideas, beliefs, values, attitudes dictated by a particular religious teaching and contribute to the formation of a religious worldview (Aryamov et al., 2014). 
Obviously, based on the psychological understanding of feelings, these experiences of believers should be manifested in the effort to defend the religious system of views, adhere to religious norms, perform religious rites, other religious activities, participate in religious ceremonies and so on. Religious feelings, like any other, are characterized by stability, depth, duration of experiences and thus differ from emotions that are not long and lasting. The objective side of the crime under Article 161 of the Criminal Code of Ukraine (2001), is characterized by public action, which is expressed in 1) incitement to religious hate and hatred, 2) insulting the feelings of citizens in connection with their religious beliefs, 3) direct or indirect restriction of rights or establishment of direct or indirect privileges of citizens beliefs.

When it comes to the manifestations of the objective side of the crime under Article 161 of the Criminal Code of Ukraine (2001), we must pay attention to the actions from which a person must refrain from the threat of criminal punishment. That is, there must be a clear list of rules, norms, principles, dogmas of religious content, violation of which may cause insult to the feelings of citizens in connection with their religious beliefs. With the existing wording of Article 161 of the Criminal Code of Ukraine, the legislator establishes liability for acts that have no legal meaning. To understand and qualify the act as offending the feelings of a citizen in connection with his religious beliefs, it is necessary to refer to the sources and norms of religion, which describe these norms, rules for performing certain rites, rules of conduct in places of religious ceremonies, etc. However, confessional norms are not part of the legislation and legal system of Ukraine, so the assessment of the image of a citizen's feelings in connection with religious beliefs is in the realm of subjective assessment and perception.

This situation is contrary to the principles of justice and legality. It is seen that criminal law can take under protection only those social relations that have a legal meaning, have certain legal boundaries. The object of criminal protection must be meaningfully accurate and understandable. Before pointing to the object of criminal law protection, it should be given legal meaning within the regulatory branches of law, because the criminal law can protect only those relations that are already regulated by positive branches of law (Bondarenko, 2014).

Violations of the right to freedom of religion can be manifested, for example, in certain cynical actions with objects of religious worship (burning of sacred books, overthrow of the cross), cynical inscriptions, drawings, other images, insulting statements about religious beliefs, and so on. It should be emphasized that these are public actions, i.e. those that take place in public places (in parks, shops, on the street, etc.), or information posted on websites, social networks, published through the media, etc., i.e. information is communicated to an unlimited amount person. 
Sophia Ya. Lykhova, Borys D. Leonov, Tetiana D. Lysko, Natalya K. Shaptala y Sergiy I. Maksymov

640

Criminal-legal ensuring of freedom of religion in modern conditions: a comparative analysis

There is a fine line between violating the rights of others and expressing one's views. It should be noted that the signs of this crime do not include the expression of their own opinions, views, judgments, even their public expression among believers, dictated by the rejection of certain religious teachings, but what is expressed in an acceptable form does not offend the religious feelings of others. violates generally accepted norms and rules of conduct. Quite dangerous in this context is the provision of paragraph 3 of Article 37 of the draft Law $(2019 ; 2020)$ "On Media in Ukraine" No. 2693 of 27.12.2019 and 2693-2 of 29.05.2020, which proposes to note that on the territory of Ukraine (including media entities) it is prohibited to disseminate statements that are discriminatory against individuals and their groups on the basis of ethnic origin, nationality, race, religion and belief, age, sex, physical disabilities, health status, sexual orientation or other grounds. Once again, this bill is submitted to the Verkhovna Rada, but it returned for revision.

If such a law is passed, none of us will be able to freely express a critical attitude towards people who have a non-traditional sexual orientation, profess a religion based on certain "specific" dogmas and contradict our own beliefs, including religious organizations that preach and support the creation of a traditional family, traditional family values. This provision contradicts the constitutionally guaranteed right to freedom of thought and speech, to free expression of one's views and beliefs (Article 32 of the Constitution of Ukraine, 1996). In this case, the expression of one's own religious beliefs in any way should not offend the religious views of another person, ie should not contain an insult to any religious beliefs or religion in general, or signs of any crime or threat to commit it, as well as exclude incitement to committing a crime based on religious intolerance or hatred.

The subjective side of this crime is characterized by direct intent. The subject is aware that he is committing public actions aimed at violating religious freedom. As demonstrated above in this article, the criminal law of some foreign countries clearly and unambiguously defines the subjective side of the crime, which encroaches on freedom of religion, which makes it possible to avoid errors of law enforcement. It is emphasized that this act is committed not only with malicious intent, but also has a specific purpose - to insult the feelings of citizens in connection with their religious beliefs (for example, Article 170 of the Criminal Code of Israel, 2010).

Currently in Ukraine at the law enforcement level it is determined that the obligatory sign of the subjective side of the analyzed corpus delicti is the goal - to incite religious hatred, offend the feelings of citizens in connection with their religious beliefs, restrict rights or establish direct or indirect privileges of citizens. religious beliefs. It is difficult to set a goal, because it is the actual result that the subject of the crime wants to achieve by committing a socially dangerous act. The goal must be manifested in specific actions 
aimed at achieving it. Therefore, researchers recommend determining the goal taking into account not only the testimony of the person, but also the objective characteristics of his actions. Regarding the algorithm for determining the purpose of offending the feelings of citizens in connection with their religious beliefs, scientists suggest evaluating any action taken at the place of religious rites and contrary to the established and acceptable rules of conduct, if it is aggressive and cynical. The combination of the content of the action and the place of their commission clearly indicate the purpose (Fedotova, 2016).

The absence of signs in the law that characterize the image of feelings cause inaccuracy in the understanding of this terminological phrase. Insult should be understood as an openly expressed, cynical, immoral form of communication that is humiliating for a person. In the context of insulting the feelings of citizens in connection with their religious beliefs, the image should be understood as a humiliation of values, ideas, views of the believer, expressed in an obscene manner. The presence of this goal can be detected not only from the testimony of the victim, but also through the nature of the acts committed (cynical, rude actions that express a clear disrespect for the views and ideals of the believer). The motive does not affect the qualification, so criminal acts can be committed not only in connection with the disgust or rejection of a religion, ie on the grounds of religious intolerance, but for other reasons (for example, hooliganism, racial or national intolerance).

The subject of the crime can be any natural sane person who has reached the age of criminal responsibility Public desecration of religious or liturgical literature, objects of religious worship, signs, emblems, symbols or attributes or their damage or destruction, committed for the purpose of insulting the religious feelings of believers, are also liable under Article 161 of the Criminal Code of Ukraine (2001). Summing up, it should be noted that Article 161 of the Criminal Code of Ukraine needs improvement. Unclear legislative wording causes problems in qualifying the feelings of citizens in connection with their religious beliefs, and the lack of standard approaches to the responsibility of representatives of different denominations indicates a violation of the most important constitutional principle of equality before the law. In the literature, there were proposals to supplement the Criminal Code with rules on criminal liability for disclosing the secrecy of confession, forcing a priest to give evidence or testimony, etc. (Marysyuk, 2003).

Emphasizing that the disposition of Article 161 of the Criminal Code of Ukraine (2001) contains a number of evaluative concepts such as "incitement to religious hate and hatred", "insult to the feelings of citizens in connection with their religious beliefs", etc., some scholars have proposed to supplement Part 1 of Article 161 of the Criminal Code on the grounds of "causing significant harm to the rights, freedoms and interests of individuals or citizens". As V.M. Pankevych points out, significant damage 
Sophia Ya. Lykhova, Borys D. Leonov, Tetiana D. Lysko, Natalya K. Shaptala y Sergiy I. Maksymov

is material and intangible and is determined taking into account all the specific circumstances of the case (2010). The argument in favor of such an innovation is an attempt to specify the degree of public danger of this crime. However, it should be noted that the very concept of "significant damage" also belongs to the category of evaluative and therefore can not perform the expected function of specifying the degree of public danger of the crime under Article 161 of the Criminal Code of Ukraine (2001). Instead, the transformation of the corpus delicti from formal to material will complicate the already difficult procedure of proving, will lead to the introduction of the measurement of this damage, which is usually intangible.

\section{Conclusions}

Thus, the current version of Article 161 of the Criminal Code of Ukraine (2001) contradicts the rules of legal technique and legal certainty, as it contains specific explanatory categories not explained by the legislator. This problem can be solved by specifying a list of specific manifestations of criminal behavior, considering the specifics of the subjective side. A wide range of such options can be borrowed from the criminal law of some foreign countries, as analyzed above. In addition, the concepts of "religious feelings", "insult of citizens' feelings in connection with their religious beliefs", "religious beliefs", "religious enmity", "religious hatred" should be defined and enshrined in a special law, taking into account the system of life values that a person is guided by in connection with belonging to a particular religious teaching.

The very feeling of belonging to this religious culture should be the basis for defining religious feeling. The insult to the feelings of citizens in connection with their religious beliefs can be defined as a negative assessment of their religious teachings, which is expressed in obscene degrading form, accompanied by gross violations of public order, expresses a clear disrespect for the generally accepted rules of conduct and morality, but with respect for the freedom of the individual to freely express their views and beliefs. It should be emphasized that there is an organic combination of both of these signs $\square$ images of feelings in connection with the religious beliefs of citizens and gross violations of public order on the grounds of obvious disrespect for society. It is mandatory to establish direct intent to commit these actions and a special purpose.

To ensure the integral and systematic provision of the right to freedom of religion, special norms on criminal liability for violation of freedom of religion should be systematically separated into a separate section of the Special Part of the Criminal Code of Ukraine. This will make it possible to identify a common generic object of these encroachments, to establish a conceptual apparatus for this specific group of criminal offenses, to 
harmonize them with international standards. These shortcomings of Article 161 of the Criminal Code of Ukraine (2001) lead to significant difficulties in law enforcement practice.

\section{Bibliographic References}

ALONKIN, Oleksiy. 2010. The human constitutional right to freedom of thought and religion and guarantees of its implementation in Ukraine. National Academy of Internal Affairs. Kyiv, Ukraine.

ANNUAL REPORT OF THE COMMISSIONER FOR HUMAN RIGHTS OF THE VERKHOVNA RADA ON THE STATE OF OBSERVANCE AND PROTECTION OF HUMAN AND CIVIL RIGHTS AND FREEDOMS IN UKRAINE. 2019. Available online. In: https://www.pfu.gov. ua/2121574-shhorichna-dopovid-upovnovazhenogo-verhovnoyi-radyukrayiny-z-prav-lyudyny-pro-stan-doderzhannya-ta-zahystu-pravi-svobod-lyudyny-i-gromadyanyna-v-ukrayini-za-2019-rik-wwwombudsman-gov-ua/. Consultation date: 19/04/2020.

ARYAMOV, Andrey; RUEVA, Yevgeniya; PONOMARENKO, Vladimir. 2014. "Variation on the topic of criminal law protection of religious freedom in the Russian Federation". In: Bulletin of Higher Educational Institutions. No. 3, pp. 4-16.

BELGIAN CRIMINAL CODE. 1867. On June 8. Available online. In: https://www.legislationline.org/documents/section/criminal-codes/ country/41/Belgium/show. Consultation date: 17/04/2020.

BILASH, Oleksandr. 2015. Criminal legal characterization of illegal actions concerning religious buildings or shrines. Oleksandra Garkusha Publishing House. Uzhhorod, Ukraine.

BONDARENKO, Vadim. 2014. "Violation of the right to freedom of conscience and religion: the problem of determining the basis of criminal law protection". In: Bulletin of the Saratov State Law Academy. Vol. 2, No. 97, pp. 202-205.

BORZENKOV, Gennadiy; KOMYSSAROV, Vladimir. 2002. Criminal Law Course. Russian Federation: Zerczalo-M. Moscow, Russia.

CHARTER OF THE UNITED NATIONS. 1945. Available online. In: https:// www.un.org/en/sections/un-charter/un-charter-full-text/index.html. Consultation date: 16/04/2020.

CONSTITUTION OF UKRAINE. 1996. On June 28. Available online. In: https://zakon.rada.gov.ua/laws/show/254\%Do\%BA/96-\%Do\%B2\% D1\%80\#Text. Consultation date: 15/04/2020. 
Sophia Ya. Lykhova, Borys D. Leonov, Tetiana D. Lysko, Natalya K. Shaptala y Sergiy I. Maksymov

CONVENTION AGAINST DISCRIMINATION IN EDUCATION. 1960. On December 14. Available online. In: http://portal.unesco.org/en/ev.phpURL_ID=12949\&URL_DO=DO_TOPIC\&URL_SECTION=201.html. Consultation date: 16/04/2020.

CONVENTION ON THE RIGHTS OF THE CHILD. 1989. On November 20. Available online. In: https://www.unicef.org/child-rights-convention/ convention-text. Consultation date: 16/04/2020.

CRIMINAL CODE OF ARGENTINA. 1984. On August 27. Available online. In: http://servicios.infoleg.gob.ar/infolegInternet/anexos/ 15000-19999/16546/texact.htm. Consultation date: 20/04/2020.

CRIMINAL CODE OF GEORGIA. 1999. On July 22. Available online. In: https://www.legislationline.org/download/id/8540/file/Georgia_ CC_2009_amAug2019_en.pdf. Consultation date: 20/04/2020.

CRIMINAL CODE OF JAPAN. 1907. On April 24. Available online. In: http:// www.japaneselawtranslation.go.jp/law/detail_main?re $=02 \& i a=$ o3\&vm=02\&id=196. Consultation date: $20 / 04 / 2020$.

CRIMINAL CODE OF NORWAY. 1981. On May 22. Available online. In: https://www.legislationline.org/documents/section/criminal-codes/ country/11/Norway/show. Consultation date: 20/04/2020.

CRIMINAL CODE OF SPAIN. 1995. On November 24. Available online. In: https://www.legislationline.org/documents/section/criminal-codes/ country/2/Spain/show. Consultation date: 20/04/2020.

CRIMINAL CODE OF THE FEDERAL REPUBLIC OF GERMANY. 1971. On May 15. Available online. In: https://www.legislationline.org/ documents/section/criminal-codes/country/28/Germany/show. Consultation date: 20/04/2020.

CRIMINAL CODE OF THE FRENCH REPUBLIC. 1994. On March 1. Available online. In: https://www.legislationline.org/download/id/3316/file/ France_Criminal\%20Code\%2Oupdated\%200n\%2012-10-2005.pdf. Consultation date: 20/04/2020.

CRIMINAL CODE OF THE KYRGYZ REPUBLIC. 1997. On October 1. Available online. In: https://cis-legislation.com/document.fwx?rgn=233. Consultation date: 20/04/2020.

CRIMINAL CODE OF THE NETHERLANDS. 1881. On March 3. Available online. In: https://www.legislationline.org/documents/section/ criminal-codes/country/12/Netherlands/show. Consultation date: 20/04/2020. 
CRIMINAL CODE OF THE PEOPLE'S REPUBLIC OF CHINA. 1979. On July 1. Available online. In: https://www.fmprc.gov.cn/ce/cgvienna/eng/ dbtyw/jdwt/crimelaw/t209043.htm. Consultation date: 20/04/2020.

CRIMINAL CODE OF THE REPUBLIC OF AZERBAIJAN. 1999. On December 30. Available online. In: https://www.wipo.int/edocs/lexdocs/laws/en/ az/az017en.pdf. Consultation date: 20/04/2020.

CRIMINALCODEOFTHEREPUBLICOF BELARUS. 1999. OnJuly 9. Available online. In: https://cis-legislation.com/document.fwx?rgn=1977. Consultation date: 20/04/2020.

CRIMINAL CODE OF THE REPUBLIC OF BULGARIA. 1968. On May 1. Available online. In: https://www.legislationline.org/download/ id/8395/file/Bulgaria_Criminal_Code_1968_am2017_ENG.pdf. Consultation date: 20/04/2020.

CRIMINAL CODE OF THE REPUBLIC OF KAZAKHSTAN. 1997. On July 16. Available online. In: https://www.legislationline.org/documents/ id/4986. Consultation date: 20/04/2020.

CRIMINAL CODE OF THE REPUBLIC OF KOREA, on January 1, 1998. Available online. In: https://www.refworld.org/pdfid/3f49e3ed4.pdf. Consultation date: 20/04/2020.

CRIMINALCODE OFTHE REPUBLIC OF LATVIA. 1998. On June 17. Available online. In: https://www.legislationline.org/download/id/8266/file/ Latvia_CC_1998_am2018_en.pdf. Consultation date: 20/04/2020.

CRIMINAL CODE OF THE REPUBLIC OF LITHUANIA. 2000. On September 26. Available online. In: https://www.legislationline.org/download/ id/8272/file/Lithuania_CC_2000_am2017_en.pdf. Consultation date: 20/04/2020.

CRIMINAL CODE OF THE REPUBLIC OF MOLDOVA. 2002. On April 18. Available online. In: https://www.legislationline.org/download/ id/3559/file/Criminal\%20Code\%20RM.pdf. Consultation date: 20/04/2020.

CRIMINAL CODE OF THE REPUBLIC OF POLAND. 1997. On June 6. Available online. In: https://www.legislationline.org/documents/ section/criminal-codes/country/10/Poland/show. Consultation date: 19/04/2020.

CRIMINAL CODE OF THE REPUBLIC OF SAN MARINO. 2008. On June 18. Available online. In: https://www.legislationline.org/download/ id/6848/file/San\%2oMarino_law_on_prevention_elimination_ 
Sophia Ya. Lykhova, Borys D. Leonov, Tetiana D. Lysko, Natalya K. Shaptala y Sergiy I. Maksymov

646 Criminal-legal ensuring of freedom of religion in modern conditions: a comparative analysis

violence_against_women_gender_violence_2008_en.pdf. Consultation date: 19/04/2020.

CRIMINAL CODE OF THE SWISS CONFEDERATION. 1937. On December 21. Available online. In: http://www.duribonin.ch/docs/ StrafrechtAllgemeinerTeil.pdf. Consultation date: 20/04/2020.

CRIMINAL CODE OF UKRAINE. 2001. Available online. In: https://zakon. rada.gov.ua/laws/show/2341-14. Consultation date: 15/04/2020.

DANISH PENAL CODE. 2005. On December 21. Available online. In: https://www.legislationline.org/documents/section/criminal-codes/ country/34/Denmark/show. Consultation date: 20/04/2020.

DECLARATION OF PRINCIPLES ON TOLERANCE. 1995. On November 16. Available online. In: http://portal.unesco.org/en/ev.php-URL ID $=13175 \&$ URL_DO =DO_TOPIC\&URL_SECTION=201.html. Consultation date: 16/04/2020.

DEJVYS, Denis. 2006. The evolution of religious freedom as a universal human right: a study on the role of the 1981 UN Declaration on the elimination of all forms of intolerance and discrimination based on religion or belief. Federation: Novaya Yustycyya. Moscow, Russian.

DEMYANOV, Yevhen. 2018. The SBU interrogated about two dozen priests of the UOC-MP. Available online. In: https://www.unn.com.ua/uk/ news/1766247-sbu-dopitala-blizko-dvokh-desyatkiv-svyaschennikivupts-mp. Consultation date: 18/04/2020.

DRAFT LAW No. 2693. 2019. "On Media in Ukraine". On December 27. Available online. In: https://w1.c1.rada.gov.ua/pls/zweb2/ webproc4_1?pf3511=67812. Consultation date: 20/04/2020.

DRAFT LAW No. 2693-2 .2020. "On Media in Ukraine”. On May 29. Available online. In: http://w1.c1.rada.gov.ua/pls/zweb2/ webproc4_1?pf3511=68970. Consultation date: 20/04/2020.

FEDOTOVA, Yuliya. 2016. "Insulting the religious feelings of believers and criminal law: work on mistakes" In: Legal Science and Law Enforcement Practice. Vol. 1, No. 35, pp.199-120.

FISUN, Yuliya. 2005. International legal regulation of the institute of religious security. Institute of Legislation of the Verkhovna Rada of Ukraine. Kyiv, Ukraine.

ILYIN, Yevgeniy. 2008. Emotions and feelings. Piter-Press. St. Petersburg, Russian Federation. 
INTERNATIONAL COVENANT ON CIVIL AND POLITICAL RIGHTS. 1976. Available online. In: http://www.un.org.ua/images/International Covenant_on_Civil_and_Political_Rights_CCPR_eng1.pdf. Consultation date: 16/04/2020.

KRYVENKO, Leonid. 2014. Information of the Verkhovna Rada of the USSR (VVR). Available online. In: https://cyclop.com.ua/content/ view/990/58/1/4/\#6528. Consultation date: 17/04/2020.

LASHCHUK, Yefrem. 2005. The subject of a crime in the criminal law of Ukraine. National Academy of Internal Affairs. Kyiv, Ukraine.

LAWOF UKRAINENo.987-XII.1991. "On Freedom ofConscienceand Religious Organizations”. On April 23. Available online. In: https://zakon.rada. gov.ua/laws/show/987-12\#Text. Consultation date: 15/04/2020.

LYKHOVA, Sophia. 2006. Crimes in the sphere of realization of civil, political and social rights and freedoms of a person and a citizen (section $\mathrm{V}$ of the Special Part of the Criminal Code of Ukraine). Publishing and Printing Center "Kyyivskyj Universytet. Kyiv, Ukraine.

MAKLAKOV, Anatoliy. 2000. General psychology. Piter. St. Petersburg, Russian Federation.

MALYSHKO, Volodymyr. 2005. The constitutional human right to freedom of thought and religion. V.M. Koretsky Institute of State and Law. Kyiv, Ukraine.

MARKIN, Viktor. 2012. Criminal legal protection of religious freedom in Ukraine. Lviv State University of Internal Affairs Institutional Repository (LvSUIAIR). Lviv, Ukraine.

\section{MARYSYUK,}

MAZURENKO, Alyona. 2018. The SBU is searching the apartment of the head of the Kiev-Pechersk Lavra. Available online. In: https://www.pravda. com.ua/news/2018/11/30/7199786/. Consultation date: 18/04/2020.

OSTROVSKY, Oleksandr. 2014. Criminal liability for violation of the human right to freedom of religion under the criminal law of Ukraine. Lviv State University of Internal Affairs Institutional Repository (LvSUIAIR). Lviv, Ukraine.

PALIY, Maksym. 2002. Crime in the field of religion and the fight against it. V.M. Koretsky Institute of State and Law. Kyiv, Ukraine. 
Sophia Ya. Lykhova, Borys D. Leonov, Tetiana D. Lysko, Natalya K. Shaptala y Sergiy I. Maksymov

648 Criminal-legal ensuring of freedom of religion in modern conditions: a comparative analysis

PANKEVICH, Vasyl. 2010. Criminal-legal characteristics of violation of equality of citizens depending on their racial, national affiliation or attitude to religion. Institute of Legislation of the Verkhovna Rada of Ukraine. Kyiv, Ukraine.

PARASZCZUK, Joanna; DRACHUK, Serhiy. 2015. The Muslim world reacts differently to the shooting in Paris. Available online. In: https://www. radiosvoboda.org/a/26783482.html. Consultation date: 17/04/2020.

PCHELYNCEV, Anatoliy. 2012. Freedom of religion and activities of religious associations in the Russian Federation: constitutional and legal framework. Yurisprudentsiya. Moscow, Russian Federation.

PENAL LAW OF ISRAEL. 2010. Article-By-Article Translation from Hebrew Into Russian. Available online. In: http://library.khpg.org/files/ docs/1375279180.pdf. Consultation date: 20/04/2020.

PRAVDA. 2012. Prime Minister Of Turkey: Islam Brings Peace To The World, And American Film Is A Hostile Provocation. Available online. In: https:// www.pravda.com.ua/news/2012/09/14/6972727/. Consultation date: 17/04/2020.

PROTESTS ERUPT IN MONTENEGRO OVER RELIGION LAW: SERBIAN ORTHODOX CHURCH RIGHTS UNDER THREAT. 2019. Available online. In: https://ua.112.ua/svit/u-chornohorii-spalakhnuly-protestycherez-zakon-pro-relihiiu-prava-serbskoi-pravoslavnoi-tserkvy-pidzahrozoiu-520138.html. Consultation date: 17/04/2020.

REPORT ON THE HUMAN RIGHTS SITUATION IN UKRAINE. 2019 . February 16 To May 15, 2019. Available online. In: https://www.ohchr. org/Documents/Countries/UA/ReportUkraine16Feb-15May2019_ UA.pdf. Consultation date: 18/04/2020.

REPORT ON THE HUMAN RIGHTS SITUATION IN UKRAINE. 2019b. MAY 16 TO AUGUST 15, 2019. Available online. In: https://www.ohchr.org/ Documents/Countries/UA/ReportUkraine16May-15Aug2019_UA.pdf. Consultation date: 18/04/2020.

RESOLUTION OF THE DISTRICT ADMINISTRATIVE COURT OF KYIV. 2014. CASE No. 826/19616/13-a, on January 28. Available online. In: https://reyestr.court.gov.ua/Review/37188411. Consultation date: 18/04/2020.

RESOLUTION OF THE GENERAL ASSEMBLY No. 36/55. 1981. "ON PREAMBLE OF THE DECLARATION ON THE ELIMINATION OF ALL FORMS OF INTOLERANCE AND OF DISCRIMINATION BASED ON RELIGION OR BELIEF", on November 25, 1981. Available 
online. In: https://www.ohchr.org/EN/ProfessionalInterest/Pages/ ReligionOrBelief.aspx. Consultation date: 22/04/2020.

RESOLUTIONOFTHEGENERALASSEMBLYNo.47/135.1992. “On Preamble of The Declaration On The Rights Of Persons Belonging To National Or Ethnic, Religious And Linguistic Minorities”. On December 18. Available online. In: https://www.ohchr.org/EN/ProfessionalInterest/Pages/ Minorities.aspx. Consultation date: 16/04/2020.

RESOLUTION OF THE ODESSA DISTRICT ADMINISTRATIVE COURT. 2012. CASE No. 1570/2775/2012 May 7. Available online. In: http:// www.reyestr.court.gov.ua/Review/24011680. Consultation date: 18/04/2020.

ROUN, Mike. 2003. The right to freedom of religion or belief. University of Minnesota Human Rights Center. Minnesota, USA.

SEREDA, Sergey. 2017. "Criminal legal mechanisms for protecting the right to freedom of conscience and religion in Russia" In: Penytencyarnaya Nauka. Vol. 2, No. 38, pp. 21-26.

SHVYDCHENKO, Ihor. 2009. Freedom of religion as an object of criminal law protection. National Academy of Internal Affairs. Kyiv, Ukraine.

STATISTICS FROM THE MINISTRY OF CULTURE. 2020. In Ukraine, The Number of Unregistered Religious Communities Has Increased. Available online. In: https://www.irs.in.ua/ua/statistics-of-religiousorganizations-in-ukraine-2020. Consultation date: 17/04/2020.

THE SWEDISH CRIMINAL CODE. 1962. On December 21. Available online. In: https://www.legislationline.org/documents/section/criminalcodes/country/1/Sweden/show. Consultation date: 20/04/2020.

UNIVERSAL DECLARATION OF HUMAN RIGHTS. 1948. Available online. In: https://www.un.org/en/universal-declaration-human-rights/. Consultation date: 16/04/2020.

YARMOL, Liliya. 2003. Freedom of religion: legal support in Ukraine (general theoretical research). National University "Odessa Law Academy". Odessa, Ukraine. 

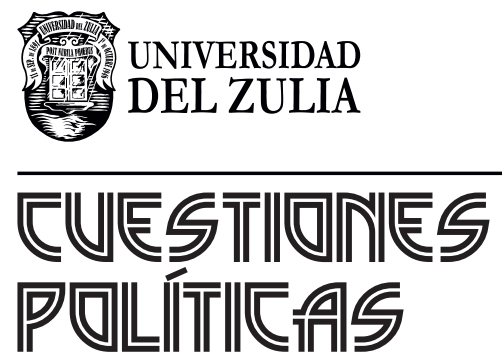

Vol.39 No 68

Esta revista fue editada en formato digital y publicada en enero de 2021, por el Fondo Editorial Serbiluz, Universidad del Zulia. Maracaibo-Venezuela 